\title{
The Role of Small Powers in Great Power Politics: A Case Study of Pakistan
}

\author{
Dr. Allauddin Kakar \\ Assistant Professor/ DS Research \\ Command and Staff College Quetta - Pakistan \\ allauddin_kakar@yahoo.com \\ Azeem Khalid (Corresponding Author) \\ PhD Scholar \\ Jinan University Guangzhou, China. \\ Lecturer of International Relations \\ COMSATS University Islamabad \\ azeem.khalid@live.com \\ Soomro Shabbir Ahmed \\ PhD Scholar at Jinan University \\ Guangzhou, China \\ shabbir_ahmed24@hotmail.com
}

\begin{abstract}
The role of small powers in competition between great powers is crucial. To achieve worldwide strategic goals and increase their political and military might great powers form alliances and exploit smaller states for their strategic objectives. On the other hand, small states enter in alliance with great powers to receive military aid and secure its strategic goals. In this context, this research paper explains role of Pakistan in great power competition. Pakistan is a significant geostrategic location and has been central to this competition. Historically, Pakistan was US ally during cold war era and remained part of its subsequent defense organizations. Besides, Pakistan remained pivotal in helping US to achieve her strategic goals during Soviet invasion of Afghanistan. The Indian factor and apprehension of communist threats compelled the country to enter US alliance and to receive defense support. Currently, the growing US-China strategic competition has pushed Pakistan towards a difficult position. The benefits received from Chinese side through CPEC are way more than the US has ever given to Pakistan. Though Pakistan has clarified to be neutral
\end{abstract}




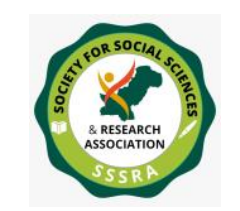

Pak. Journal of Int'L Affairs, Vol 4, Issue 2 (2021)

The Role of Small Powers in Great ...

in US-China competition, but the growing Sino-Pakistan defense and economic cooperation is witnessing a shift in Pakistan's stated position.

Key words: Great Powers competition, Small states, Cold War, Bipolarity, Multipolarity, China-Pakistan cooperation, CPEC.

\section{Introduction}

Small states in the right places are regarded very important by big powers. Small states are considered highly important in great power competition. To achieve strategic goals, big power prefer to form alliance with small states and exploit their role against competing power (Brunnermeier, Doshi, \& James, 2018). Small states, on the other hand, sometimes prefer to join alliances to meet its military and economic concerns and in some cases they prefer to be neutral. In this backdrop, Pakistan has always played central role in great power competition due to its geostrategic importance, the Indian factor and the communist threats. Historically, Pakistan was part of US-led western block during cold war era and Soviet invasion of Afghanistan. Pakistan signed defense pacts such as South Asian Treaty Organization (SEATO) and Central Treaty Organization (CENTO). After 9/11, Pakistan played role of a 'frontline' states in US-led global campaign against terrorism. The resurgence of Russia and the rise of China have challenged the US hegemonic position in the world and a new era of great power competition is on its rise. The emergence of Russia and China have produced a shift in the system of power distribution from unipolar to a multipolar world. The United States has officially recognized the return of great power competition with Trump administration's release of its National Strategy (NSS) at the end of 2017. The US policy makers have argued that Asia will be the main focus of this emerging great power competition.

The post-Second World War period witnessed the rise of competition between the United States and Soviet Union. After the end Second World War, competition between these two great powers started and became prevalent (McMahon, 2013). Afterwards, states that joined the US-led bloc became known as the Western Bloc, while those that allied with Soviet Union were called as the Eastern Bloc. Each great power was pursuing its foreign policy objectives to win the Cold War. The United States was pursuing the policy of doctrine of containment, which aimed to contain the expansion of communist ideologies. On the other hand, the Soviet Union's foreign policy goals were to spread and strengthen the position of socialism throughout the world (Hoffmann, 1987). These two wholly opposed strategies provided the framework for competition within a bipolar system of power distribution and future conflict between the two world superpowers. Pakistan was part of US-led western bloc and played important role in this great power competition between Russia and US. 


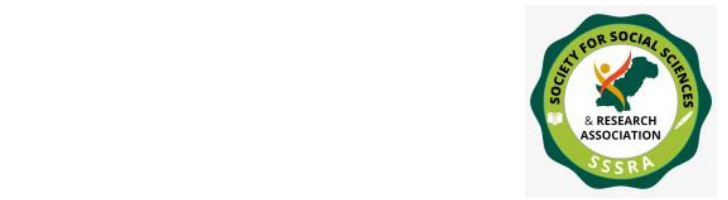

South Asia has been central to great power competition (Goh, 2007). In current scenario, the growing US-India strategic partnership and the deepening Sino-Pakistan defense and economic cooperation is making Pakistan-US future relationships unclear (Jahangir \& Khan, 2020). Pakistan which was close ally of US in past and during the global war against terrorism is now unlikely to support US in its strategic competition with China - an all-weather and time-tested friend of Pakistan. The emerging great power competition between China and US will define the twenty first century world. For US, strategic competition with China is a key national security concern in recent times. Competition between these two great powers is impacting nearly every aspect of geopolitics. These two big power are engaged in finding allies to compete each other in this new ear of great power competition. Though Pakistan has so far played neutral role in US-China hegemonic competition, but it is likely to play crucial role in this competition due its geostrategic significance and the growing US-India strategic partnership.

The current US desire to make India its reliable ally in the region is explained by this dynamic. As partnership between United States and India is cementing, the future of US relations with Pakistan is becoming unclear (Khan, 2017). Hence, Pakistan has quest for more reliable partners. By assessing Pakistan's role during the Cold War, during Soviet invasion of Afghanistan, after /11, and the current multipolar system of power distribution, this research paper analyzes the role of Pakistan in great power politics. Data for this study has been collected through secondary sources with secondary data analysis.

\section{Literature Review}

Small states play crucial role in great power politics. Big powers regard role of small states vital for their strategic goals. A small state with unique geographical location is of great importance to a great power (Lebow, 1997). Such a state play pivotal role in great power politics. According to scholars, in relationships between Great Power and Non-Great Power States, most of the times small states remain between two fundamental actions when it comes to competing powers: either to cede their sovereignty to bandwagon with competing powers or to became ally of great power to protect their sovereignty to balance against competing powers (Walt, 1985). Expert of international relations disagree about action better fulfill strategic interests of small states, most are of the view that because states aim to maximize their autonomy and protect their sovereignty, they will balance. According to Stephen Walt, which is a prominent scholar in the realist school, states generally choose to balance than bandwagon because they have potential to gain more influence by balancing hegemonic competing states than by ceding to their hegemony (Walt, 1985). He is of the view that hegemons and competing 


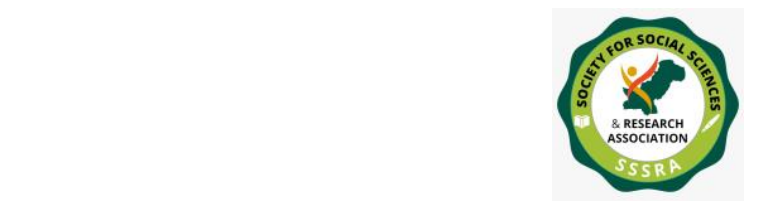

The Role of Small Powers in Great ...

powers scare smaller states by compelling them to "join alliances [to] avoid domination by stronger powers" (Walt, 1985). Some experts are of the opinion that states prefer to bandwagon. According to Robert S. Ross small states "tend to [bandwagon] rather than balance [against rising] powers" because small states are "sensitive to local variation" in the capabilities of nearby rising powers (Ross, 2006). Critics of bandwagoning state that minority of states prefer to do so merely because they have no other prefer choice.

Harris (2020) in his study states that'Pakistan in the era of great power competition' explains the post global war on terrorism era which witnessed a multipolar system of power distribution because of the revival of Russia and the rise of China. The author explains that Central Asia has become central place of strategic competition of the three great powers. United States is pursuing its goals to make allies in the region that reliable of supporting its global strategy. In this study, the author has stated that Pakistan - a historical US ally, is no more ready to support the US in achieving objectives in the region. United States has preferred India as more compatible ally in the region. As relationships between India and US is strengthening, the future of US-Pakistan ties is becoming uncertain (Harris, 2020).

\section{Great Power Competition and Role of Smaller States}

Experts of international relations believe that small states when face competing powers they choose between two fundamental actions: either cede their sovereignty to bandwagon with great powers or prefer to defend their independence by entering into alliances with great powers in order to balance against competing powers. While scholars disagree about which action better meets strategic interests of small states. Most of the scholars are of the view that because states aim to maximize their autonomy and protect their sovereignty, they are more likely to balance. According to Stephen Walt, a leading scholar in the realist school, states generally prefer to balance than bandwagon because they are able to obtain more influence by balancing hegemonic states than by ceding to their hegemony (Walt, 1985). He explains that "hegemons and competing powers scare smaller states by forcing them to join alliances to avoid domination by stronger powers" (Walt, 1985). However, some experts believe that states are more likely to bandwagon. Robert S. Ross argues that "small states tend to bandwagon rather than balance against rising powers because small states are sensitive to local variation in the capabilities of nearby rising powers" (Ross, 2006).

In the case of Pakistan, instability in Pakistan has played major role in developing relationships between Pakistan and the United States. Robert McMahon explains how Pakistan entered into US-led alliance, specifically through the lens of Cold War, because 


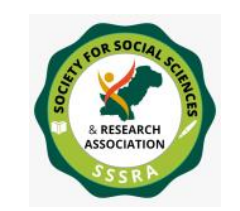

The Role of Small Powers in Great ...

Pakistan needed US support to recover from three wars it had fought with India early in its history24. Hussain explains Pakistan's complex relations with the US during the Global War on Terrorism created challenges for relations between US and Pakistan. He explains that providing Pakistan with US aid and eliminating sanctions addressed instability concerns of Pakistan and for these reasons Pakistan became US ally during the unipolar system of power distribution (Hussain, 2005).

\section{Great Power Competition and Role of Pakistan}

\section{Cold war}

The post-Second World War period witnessed the rise of competition between the United States and Soviet Union. After the end Second World War, competition between these two great powers started and became prevalent (McMahon, 2013). Afterwards, states that joined the US-led bloc became known as the Western Bloc, while those that allied with Soviet Union were called as the Eastern Bloc. Each great power was pursuing its foreign policy objectives to win the Cold War. The United States was pursuing the policy of doctrine of containment, which aimed to contain the expansion of communist ideologies. On the other hand, the Soviet Union's foreign policy goals were to spread the spread and strengthen the position of socialism throughout the world (Hoffmann, 1987). These two wholly opposed strategies provided the framework for competition within a bipolar system of power distribution and future conflict between the two world superpowers.

Pakistan was central to cold war period. Pakistan due to geographical and strategic compulsions played crucial role during Cold war era. To understand how it tried to meet its issues, and how it was ally for achieving the strategic needs of big powers, Pakistan and the big powers remained closely linked during high-power rivalry during Cold war era. From the end of the Second World War until the collapse of Soviet Union in year 1991, the world's system of power distribution was based on bipolarity caused by the competition between big powers-United States and Soviet Union. Rivalry between great powers also spread into South Asia, resulting in an alliance between the United States and Pakistan. The US was in need of an ally in the region in close proximity to Soviet Union, Pakistan was in need of an ally due to economic and political instability (Mcgarr, 2013).

Pakistan and its arch rival-India adopted different approaches during the Cold War. This had brought about the alliance between Pakistan and the United States and India declared to be neutral player. Pakistan was quick to align itself with the western 


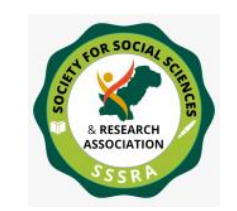

The Role of Small Powers in Great ...

bloc. Pakistan could play role of a neutral state and eagerly sought partnership with great powers in order to address its internal and external security concerns. Pakistan's' membership in collective defense and military alliance organizations - South Asia Treaty Organization (SEATO) and Central Treaty Organization (CENTO), aimed to prevent spread of communism in South Asia and the Middle East, congealed its position as potential partner with the Western Bloc (Cohen, 2009).

\section{Significance of South Asia for Great Powers}

South Asia became central place for the competition during the Cold War between those two great powers-Soviet Union and the United States. At the beginning of the Cold War, it became evident that South Asia would play decisive role in the great power politics. .46 According to McMahon, the subcontinent contained "one-fifth of the total world population on a land mass equal to that of Europe," and proximity of the region to the Middle East and to the major sea routes that linked Europe to East Asia enhanced the significance of its strategic location. That being the case, preventing the Soviets from getting leverage in the region rapidly became main objective of US foreign policy, which sought to prevent the spread of communism in South Asia. McMahon says that U.S. policymakers were "convinced that the Soviet Union stood poised to capitalize [on] the political instability, economic distress, and social chaos" that was occurring throughout the world. He also states that U.S. intelligence agencies warned that unless the United States could "secure the goodwill of these newly liberated [countries, South Asian states might] become aligned with the U.S.S.R" (McMahon, 2013).

Nuclear issues, persistent security dilemmas, and ethnical religious differences are factors which affect peace in South Asia. For example, the United States and China's respective cooperation with India and Pakistan, particularly following the US-Indian and Pak-China nuclear deals, indicate the firm politico-economic and strategic relationships which both these great powers are cultivating with the two South Asian rivals.

\section{US-USSR}

Rivalry between the USA and USSR started at the end of Second World War. Thereafter, states that became part of US-led alliance became known as the western Bloc, while those that joined the Soviet alliance were known as the Eastern Bloc. Each superpower was pursuing the objective to win Cold War (Bisley, 2004). The United States was pursuing the doctrine of containment, which aimed to contain the expansion of communism. Containment was first introduced in year 1947 by diplomat George F. Kennan, who articulated the significance of containing the spread of communism to 


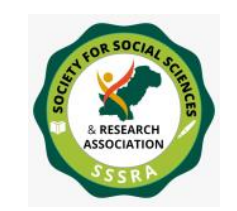

maintain US security. On the other hand, the Soviet Union's foreign policy was based on the concept to spreading and strengthening the position of socialism across the world. These two opposed strategies provided the framework for competition within a bipolar system of power distribution and future conflict between the two great powers.

Rivalry between the two great powers expanded into South Asia. At the onset of the Cold War, it became evident that South Asia would play a major role in the global bipolar power struggle. . According to McMahon, the subcontinent contained "one-fifth of the total world population on a land mass equal to that of Europe," and proximity of the region to Middle East and to other major sea routes that linked Europe to East Asia made it a strategic location (McMahon, 2013). For these reasons, containing the Soviet Union from gaining hegemonic position in South of communism in the heavily populated, and strategic subcontinent. McMahon is of the view that policy makers of the United States were "convinced that the Soviet Union stood poised to capitalize [on] the political instability, economic distress, and social chaos" that was happening through the globe $.48 \mathrm{He}$ is also of the opinion that "U.S. intelligence agencies warned that unless the United States could secure the goodwill of these newly liberated [countries, South Asian states might] become aligned with the U.S.S.R" (McMahon, 2013).

In fact, at that time, South Asia was "particularly susceptible to Communist penetration": a U.S. State, Army, Navy, Air Force Coordinating Committee position paper added that, without British oversight, both India and Pakistan faced a myriad of political and economic problems that created a vacuum of power regionally.50 Likewise, a National Security Council (NSC) position paper warned that communists' penetration into South Asia could leave the United States and its allies vulnerable and without a "foothold on the Asian mainland."51 Although these various reports and assessments made it clear that South Asia added strategic value to the United States' foreign policy goal of containment, it was still unclear which country, India or Pakistan, would be willing to form an alliance with the United States and the Western Bloc. Asia quickly became a top priority for the United States, which sought to contain the expansion.

\section{The US-China Strategic Rivalry and Pakistan}

The US-China relationships well define the $21^{\text {st }}$ century. For US, strategic competition with China is a key national security concern in recent times. The competition between these two powers is touching nearly every aspect of geopolitics. In great power competition, alliances play crucial role. For United States, to maintain stronghold in worldwide strategic competition with China, alliances play central role. The US policy shift as enunciated in 2017 'National Security Strategy' and the 2018 


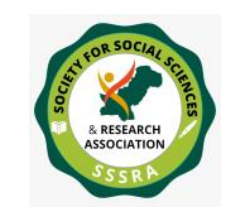

Pak. Journal of Int'L Affairs, Vol 4, Issue 2 (2021)

The Role of Small Powers in Great ...

'National Defense Strategy' documents reflects a hard approach on great power competition, particularly toward China. In 2020, during his visit to Kazakhstan, Mike Pompano warned local audiences about the danger related to business deals with China. (Daniel, 2020).

The global relations between the United States and existing and rising military and economic powers is a key component of the US national security. These emerging powers and their challenge to the US hegemonic status as Global power has led to the emergence of the Great Power Competition. The US National Defense Strategy asserts that "the central challenge to U.S. prosperity and security is the reemergence of longterm, strategic competition by ... revisionist powers, specifically China, as an economic, technological, and political competitor, and Russia, as a military opportunist power" (College of Arts and Sciences, 2021).

The growing US-China hegemonic struggle is affecting the already tense South Asian security environment, where US has cemented its ties with India to counter balance China in the region, while present phase of Sino-Pakistan relationships is witnessing deepening military and economic cooperation. The US-China hegemonic competition is escalating and the bipartisan nature of US opposition to China has pushed Pakistan toward a difficult position. Pakistan has always had strong ties with both the United States and China, based on shared security, political, and economic interests. Pakistan's continuous collaboration in Afghanistan, which will be necessary long after the US military withdrawal, is one of the current foundations of Pakistan's relationship with the US (Ali, 2020). While military and economic help has diminished, America continues to be Pakistan's greatest export market and a preferred education destination for the country's elite. China, on the other hand, has become Pakistan's largest arms supplier and has embarked on unprecedented economic cooperation through the China-Pakistan Economic Corridor (CPEC), which is expected to be worth $\$ 62$ billion (Siddiqui, 2017). Pakistani strategists also look to China for constant support in dealing with asymmetrical foe India, as well as moral backing in trying to internationalize the Kashmir issuesomething the US does not do.

\section{From SEATO to CENTO}

Soon after its inception in 1947 Pakistan joined the Western bloc. In May 1954, Pakistan signed the Mutual Defense Assistance Agreement with the United States. Later in the same year, Pakistan became member of SEATO. In the same way, it joined another mutual defense organization-Baghdad Pact in year 1955. Though United States had not

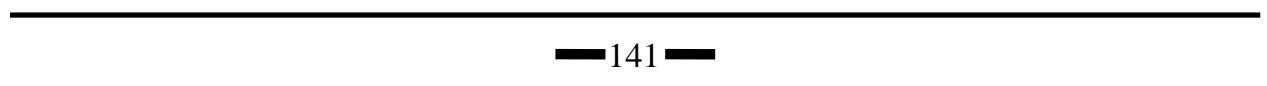




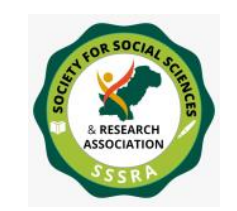

The Role of Small Powers in Great ...

joined this organization, but remained closely associated. In 1958, when Iraq announced to leave this pact, it was retitled as Central Treaty Organization (CENTO).

In early 1959, a bilateral Agreement Cooperation was signed between Pakistan and the United States which aimed at furthering the objectives of CENTO. Thus, Pakistan has been associated with United States for mutual security agreement. Pakistan is the only Asian country which was member of both SEATO and CENTO. It has been sometimes termed "America's most allied ally in Asia" (Khan, 1964).

\section{BRI and CPEC}

Besides deepening military and defense relationships between China and Pakistan, the last decade has also seen growing economic activities between the two countries. The launch of China-Pakistan Economic Corridor, which is considered flagship project of China's Belt and Road Initiative (BRI), has strengthened bilateral ties between the two countries furthermore. Pakistan's Prime Minister Imran Khan recently called CPEC "a manifestation of Pakistan-China friendship," vowing, "the government will complete it at any cost..." (Ians, 2020, July 4). In the same way, China regards CPEC a flagship project of BR.

The United States has been eying on the project from the beginning. The current US administration has perceived the project negatively. It is apparent from the US stance over the project that she is not happy with this initiative of China. The US former acting secretary of state for South and Central Asia is repeatedly criticizing the mega project. "Lack of transparency can increase CPEC costs and foster corruption resulting in an even heavier debt burden for Pakistan."17 Responding to these claims, China has argued that the debt from CPEC related projects is only $\$ 4.49$ billion, which is less than one-tenth of Pakistan's total debt.18

Pakistan's security holds great importance for China because of shared economic interests, particularly through the China-Pakistan Economic Corridor which is considered a flagship project of BRI. The mega project was launched in 2015. It consists of development projects throughout Pakistan valued at around $\$ 87$ billion and is flagship project of China's 'Belt and Road Initiative (BRI). The project according to China has provided employment opportunities to an estimated 75,000 Pakistanis and resulted in infrastructure development in highways, crawlways, and deep-sea port of Gwadar. Both in terms of militarily and economic, China and Pakistan's interest are closely linked and will likely continue to deepen in the light of growing US-Indian strategic partnership (Song, 2021). 


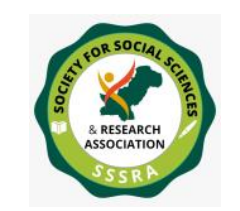

Pak. Journal of Int'L Affairs, Vol 4, Issue 2 (2021)

The Role of Small Powers in Great ...

\section{The Geo-Strategic Determinant}

The geo-strategic significance of Pakistan can best be assumed in the regional and worldwide perception. In geographical terms, Pakistan is neighbored by Afghanistan, Iran, India and China, which are major plays in global politics. Pakistan holds great importance for these countries and this raises its international stature. Pakistan is considered a gateway to Central Asia and its Arabian Sea is an easy accessible route to the Middle East. In addition, the geographical location of Pakistan connects it to four different region-South Asia, South West Asia, China and Central Asia, enhancing it's a significance. Owing to its unique geographical and geostrategic location, Pakistan has the capability to influence security, trade, ideological and social state of all these four region.

\section{Indian factor}

It is important to mention that the US policy towards South Asia was principally determined by its own interests - the Soviet Union and China. United States was pursuing its goals to contain Communism. US perceived Pakistan a more reliable partner for its strategic interests as compared to India. Pakistan's close association with the Muslim word and its geographical proximity to the Persian Gulf and Communist adversaries such as Soviet Union and China compels the US to make Pakistan an ally (Harris, 2020).

In addition, the US recognized significance of Pakistan's assistance in the containment of communism by joining South Asian Treaty Organization and Central Treaty Organization. On the other hand, primary objective of Pakistan's pursuit of strong relations with the US was not to contain Communism but to strengthen its position against its arch rival-India. Pakistan entered into defense alliances in a bid to strengthen its military and defense capabilities, which were considerably low as compare to that of India.

Relationships between Pakistan and India have since the creation of Pakistan in 1947. Since the time of creation of Pakistan, India has been a factor in Pakistan's foreign policy. The Indian threats compelled Pakistan's policy makers to find the support of a great power. It is important to note that US provided economic and military aid from 1954 to 1965 and then again during Soviet invasion of Afghanistan in 1979, which enhanced Pakistan's military capabilities to resist possible Indian aggression. India did their best to damage sovereignty of Pakistan. Pursuing this goal, India occupied Kashmir in year 1948. Besides, India imposed war on Pakistan and in 1971 she sent its armed 


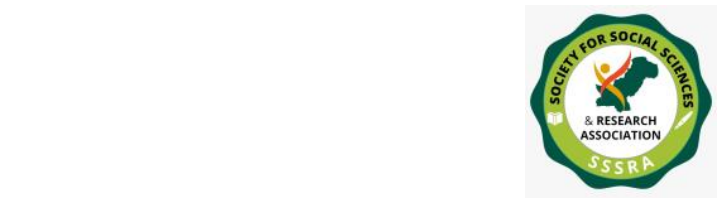

forces to assist secessionists in East Pakistan leading to partition of Pakistan and creation of Bangladesh.

National security became the basis of Pakistan foreign policy. Pakistan gave due significance to the national security. From the very beginning, the main preoccupation of Pakistan has been to ensure it security from Indian (Mehmood 2018). The negative designs of India in Kashmir, Hyderabad and Junagadh had created security threats for Pakistan. Pakistan was compelled to find great power support to strengthen its defense and economy. Pakistan preferred the United States for military aid for security concern (Salahuddin, 2005). Hence, the direction of Pakistan's foreign policy was founded on the pursuit of her security and defense for which US was considered as a more reliable country.

\section{The Afghan Factor}

When Pakistan was created in year 1947, the regional security debate revolved around two questions. First, how would a newly established Pakistan stand between India and Afghanistan on the one hand, and between India and Soviet Union on the other? (Chari, 2009) After Pakistan's formation, Afghanistan was the first Muslim country which did not recognize Pakistan in the United Nation. The first act which Afghanistan did was the refusal of Pakistan because of its territorial claim. Hence, Pakistan faced security threats from Afghanistan soon after its inception. The border dispute has been a factor affecting Pak-Afghan relations. The security threats from Afghanistan compelled Pakistan to keep its policy of strategic depth in Afghanistan as one of the foremost agenda right from the beginning. During the Soviet invasion of Afghanistan, Pakistan found an opportunity to get modern weapons from the US and also to work on its national interests.

\section{Conclusion}

This research paper discussed the role of small states in great power competition. Small states play crucial role in great power politics. Big powers regard role of small states vital for their strategic goals. A small state with unique geographical location is of great importance to a great power. Such a state play pivotal role in great power politics. In this context, the paper analyzed the role of Pakistan in great power politics. After the global campaign against terrorism, the world entered a multipolar system due to the revival of Russia and the rise of China. Asia has been central to this new system and ground to hegemonic struggle between the three great powers. The US is looking for new allies that have potential to promote its global strategy and this has led to US 
dissatisfaction of US with Pakistan which was historically a close ally during the Cold War period. Currently, the US policy towards South Asia reflects its desire to make India its preferred partner in the region which has also shifted Pakistan's policy which is now seeking more reliable partners. The paper analyzed Pakistan's role during the Cold War, the global war against terrorism, and the in the context of current situation which is dominated by multipolar power distribution.

This research paper explained how Pakistan form alliance with great powers during various systems of power distribution. The research explored that how Pakistan is situated in the competition amongst the great powers and factors which compel Pakistan to enter into alliance with great powers. In this backdrop, the paper analyzed Pakistan past role; as US ally during cold war period and the US invasion of Afghanistan. In addition, the US-Russia strategic rivalry and role of Pakistan and great power competition between US and China and the role of Pakistan. The analyzed data reveals that Pakistan geostrategic significance and strong military, religious influence in the Muslim world have driven great powers to incorporate Pakistan into their strategic goals. In addition, Pakistan due to Indian factor, the Afghan factor and communist threat joined defense organizations and became US ally. 


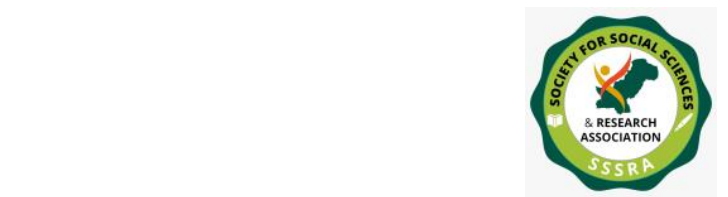

Pak. Journal of Int'L Affairs, Vol 4, Issue 2 (2021)

The Role of Small Powers in Great ...

\section{References}

Ali, S. M. (2020, December 1). The U.S.-China Strategic Rivalry and its Implications for Pakistan. Stimson. https://www.stimson.org/2020/the-u-s-china-strategic-rivalry-and-itsimplications-for-pakistan/.

Bisley, N. (2004). The End of the Cold War and the Causes of Soviet Collapse. Palgrave Macmillan.

Brunnermeier, M., Doshi, R., \& James, H. (2018). Beijing's Bismarckian ghosts: how great powers compete economically. The Washington Quarterly, 41(3), 161-176.

Chari, C. (Ed.). (2009). Superpower rivalry and conflict: the long shadow of the Cold War on the 21st century (Vol. 81). Routledge.

Cohen, S. P. (2009, December 10). Pakistan and the Cold War. Brookings. https://www.brookings.edu/articles/pakistan-and-the-cold-war/.

College of Arts and Sciences. (2021). The Great Power Competition Narrative. University of South Florida. https://www.usf.edu/arts-sciences/great-power-competition/about/thegreat-power-competition-narrative.aspx.

Daniel, M. (2020, April). How the United States Should Deal With China in Pakistan. Carneige-Tsinghua.https://carnegietsinghua.org/2020/04/08/how-united-states-shoulddeal-with-china-in-pakistan-pub-81456.

Findlay, S. (2020, August 27). Pakistan Army Muscles in on Belt and Road project. Financial Times. https://www.ft.com/content/f675981c-8

Goh, E. (2007). Great powers and hierarchical order in Southeast Asia: Analyzing regional security strategies. International Security, 32(3), 113-157.

Harris, M. X. (2020). Pakistan in the Era of Great Power Competition. Naval Postgraduate School Monterey Ca Monterey United States.

Hoffmann, E. P. (1987). Soviet foreign policy aims and Accomplishments from Lenin to Brezhnev. Proceedings of the Academy of Political Science, 36(4), 10-31.

Hussain, T. (2005). US-Pakistan engagement: The war on terrorism and beyond (Vol. 31). United States Institute of Peace. 


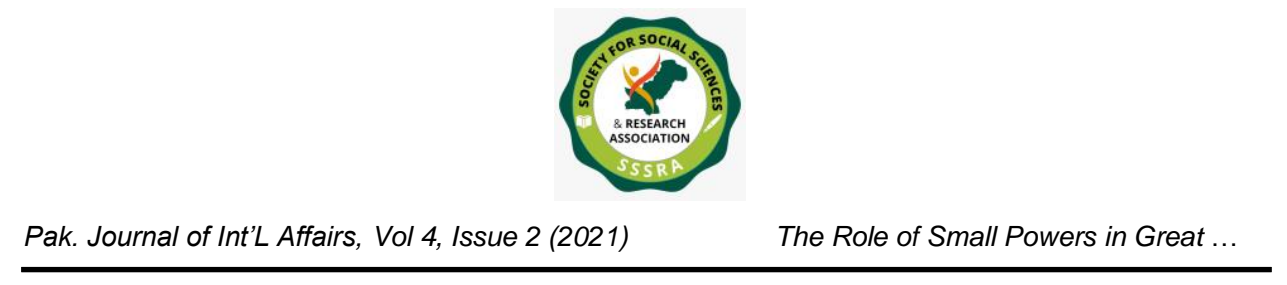

IANS. (2020, July 4). CPEC to be completed at all costs, says Imran. The Economic Times. https://economictimes.indiatimes.com/news/international/world-news/cpec-to-becompleted-at-all-costs-imran-khan/articleshow/76783727.cms?from $=m d r$

Jahangir, A., \& Khan, F. (2020). US Strategic Propensity towards India: Nuclear Bonding and Security Apprehensions for Regional Stability and Pakistan. NUST Journal of International Peace and Stability, III (1), 59-78.

Khan, M. (2017). Growing India-US Strategic Cooperation. Strategic Studies, 37(4), 97-117

Khan, M. A. (1964). The Pakistan-American Alliance: Stresses and Strains. Foreign Affairs, 42(2), 195-209.

Lebow, R. N. (1997). Small States and Big Alliances. American Political Science Review, 91(3), 705-709.

Mcgarr, P. M. (2013). The Cold War in South Asia: Britain, the United States and the Indian Subcontinent, 1945-1965. Cambridge University Press.

McMahon, R. J. (Ed.). (2013). The Cold War in the Third World. Oxford University Press.

Mehmood, N. (2018). Comparative Analysis of the Regime-Stabilization Efforts By the Soviet Union and the US-Led Coalition in Afghanistan. Naval Postgraduate School Monterey United States.

Ross, R. S. (2006). Balance of power politics and the rise of China: Accommodation and balancing in East Asia. Security Studies,15(3), 355-395.

Salahuddin, A. K. M. (2005). orcist Ethics of Kant and Human Rights. The Dhaka University Studies: Journal of the Faculty of Arts, 62, 53.

Siddiqui, S. (2017, April 12). CPEC investment pushed from $\$ 55$ b to $\$ 62$ b. The Express Tribune. https://tribune.com.pk/story/1381733/cpec-investment-pushed-55b-62b

Song, P. (2021, February 23). Will US-China Competetion Divide South Asia Along: Great Power Fault Lines. Foreign Policy Research Institute. https://www.fpri.org/article/2021/02/will-u-s-china-competition-divide-south-asia-alonggreat-power-fault-lines/.

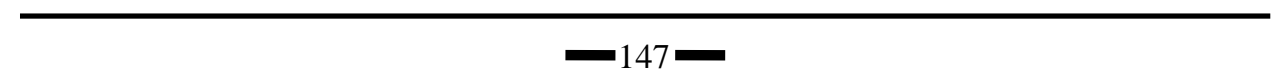


Walt, S. M. (1985). Alliance formation and the balance of world power. International Security, 9(4), 3-43. 